\title{
Paradigma Integralistik dan Toleransi Umat Beragama di Kota Palembang
}

\section{Muhammad Noupal}

Fakultas Ushuluddin dan Pemikiran Islam

Universitas Islam Negeri Raden Fatah Palembang, Indonesia

Email: muhammadnoupal_uin@radenfatah.ac.id

\section{Erina Pane}

Fakultas Ushuluddin dan Pemikiran Islam

Universitas Islam Negeri Raden Intan Lampung, Indonesia

Email: erinapane@gmail.com

\begin{abstract}
Abstrak
Paradigma integralistik dalam konteks kajian toleransi umat beragama, dimaknai sebagai paham dan konsep hubungan antar umat beragama yang toleran. Dalam paradigma integralistik, upaya mewujudkan toleransi umat beragama memerlukan kerjasama dan peran dari semua pihak, termasuk pemerintah dan tokoh agama. Hal ini karena, agama dan Negara merupakan suatu kesatuan yang tidak dapat tidak dipisahkan. Keduanya merupakan dua lembaga yang menyatu (integrated). Ini juga memberikan pengertian bahwa Negara merupakan suatu lembaga politik dan sekaligus lembaga agama. Konsep ini menegaskan kembali bahwa Islam tidak mengenal pemisahan antara agama dan politik atau Negara. Konsep seperti ini sama dengan konsep teokrasi. Toleransi umat beragama dibangun dalam beberapa aspek paradigma integralistik. Aspek-aspek tersebut yakni: toleransi dalam aspek ekonomi. Toleransi dalam aspek budaya. Toleransi dalam aspek sosial keagamaan.
\end{abstract}

Kata Kunci: Toleransi, Peran Pemerintah, Integralistik

Studi terhadap paradigma integralistik ini bermula dari keinginan memperoleh jawaban mengenai upaya untuk mencegah terjadinya konflik di daerah yang memiliki keragaman baik suku maupun agama, yang bila tidak disikapi secara bijak dapat memunculkan konflik komunal Sehubungan dengan itu, permasalahan yang ada dalam judul tersebut diidentifikasi sebagai berikut.

Untuk mengamankan masyarakat pluralis yang rentan terjadinya konflik dan membangun toleransi umat beragama melalui paradigma integralistik dapat dikaji dari berbagai aspek, yakni Pertama, aspek ekonomi, dengan melakukan upaya-upaya yang dapat mensejahterakan masyarakat, seperti pemberdayaan masyarakat berbasis keadilan dan kesejahteraan umat, dengan memberlakukan JPS 
(Jaring Pengaman Sosial), memberikan bantuan bagi keluarga yang kurang mampu, mengadakan pelatihan-pelatihan kepada masyarakat yang tidak mempunyai pekerjaan sehingga ia mempunyai keterampilan yang dapat menghasilkan uang. Kedua, aspek normatif (dokrin agama), yakni upaya memberikan kesadaran dan pemahaman yang baik mengenai pentingnya untuk hidup damai dan rukun, salah satu caranya dengan mengadakan kegiatan pengajian yang materinya seputar pentingnya menciptakan dan memelihara kerukunan dan keharmonisan hidup beragama (pengajian agama berbasis pluralitas), peran serta dan kearifan pemuka agama untuk tidak melakukan dakwah standar ganda dalam masyarakat majemuk. Ketiga, aspek politik dan hukum, yakni dengan memberlakukan sangsi yang tegas dan mengamankan siapa saja yang berbuat sesuatu hal yang dapat menyebabkan terjadinya konflik.

Artinya, untuk mencegah agar tidak terjadinya konflik yang perlu diperhatikan, yakni bagaimana kondisi sosial masyarakat itu, seperti keadaan ekonomi, situasi politik, sosial budaya, dll. Disinilah dituntut sejauh mana peran pemerintah dalam menyelesaikan masalah-masalah yang ada. Disamping itu, pemerintah juga perlu bekerja sama dengan semua pihak yang terkait, antara lain dengan pemuka agama, agamawan dan para cendikiawan teologis. Dalam hal ini juga, banyak sudut pandang dan ilmu yang dapat dipakai dalam mengkaji masalah tersebut, antara lain: ilmu ekonomi, ilmu politik, ilmu sosiologi, ilmu psikologi dan lain-lain.

Melihat begitu kompleksnya masalah yang dihadapi dalam upaya mencegah agar konflik komunal tidak terjadi, diperlukan ilmu pengetahuan yang kompeten dan dapat diharapkan sanggup memecahkan masalah ini dengan wajar. Teknologi, teologi, ilmu ekonomi, ilmu politik, ilmu antropologi budaya, ilmu hukum harus bisa disinerjikan dan dikolaborasikan dengan efektif. Karena teologi saja misalnya, tidak dapat diharapkan mampu memecahkan persoalan, apalagi teologi yang masih berpegang pada pola tradisional dan biasanya kurang menguasai pengetahuan sosiologis. Munculnya usaha pengembangan ke arah teoritis dan praktis dalam teologi seperti teologi sosial, teologi bisnis, dewasa ini sesungguhnya merupakan jawaban dari kesempitan makna teologi yang sampai sekarang ini dianut oleh mayoritas muslim di Indonesia. Dari teknologi pun juga belum cukup, karena teknik pembangunan dari sarana-sarana fisik adalah lain dari teknik menangani masalah sosial. Masyarakat tidak dapat digerakkan dalam pembangunan ini dengan hanya ditawari teknologi-teknologi canggih melainkan perlu teknik-teknik penyadaran akan perlunya kehidupan yang lebih baik. Untuk itu butuh juga ilmuilmu, misalnya psikologi atau sosiologi umum.

Uraian di atas mendeskripsikan betapa pentingnya toleransi umat beragama, agar kerukunan selalu terpelihara. Dan hal ini menjadi menarik untuk dikaji karena penulis mencoba menganalisa upaya terwujudnya toleransi umat beragama dengan menggunakan paradigma integralistik. Sebelum dideskripsikan peran pemerintah

Intizar, Vol. 23, No. 1, 2017 
p-ISSN: 1412-1697; e-ISSN: 2477-3816

http://jurnal.radenfatah.ac.id/index.php/intizar

Kota Palembang dan tokoh agama dalam membangun toleransi umat beragama melalui paradigma integralistik. Akan dijelaskan terlebih dahulu konsep dari paradigma integralistik.

\section{Konsep Paradigma Integralistik}

Paradigma dapat diartikan sebagai cara pandang seseorang terhadap diri dan lingkungannya yang akan mempengaruhinya dalam berpikir (kognitif), bersikap (afektif), dan bertingkah laku (konatif). Paradigma juga dapat berarti seperangkat asumsi, konsep, nilai, dan praktik yang di terapkan dalam memandang realitas dalam sebuah komunitas yang sama, khususnya, dalam disiplin intelektual.

Kata paradigma sendiri berasal dari abad pertengahan di Inggris yang merupakan kata serapan dari bahasa Latin di tahun 1483, yaitu paradigma yang berarti suatu model atau pola; bahasa Yunani paradeigma (para + deiknunai) yang berarti untuk "membandingkan", "bersebelahan" (para) dan memperlihatkan (deik).

Secara etimologis paradigma, berarti model teori ilmu pengetahuan atau kerangka berpikir. Sedangkan secara terminologis paradigma berarti pandangan mendasar para ilmuan tentang apa yang menjadi pokok persoalan yang semestinya dipelajari oleh suatu cabang ilmu pengetahuan. Jadi, paradigma ilmu pengetahuan adalah model atau kerangka berpikir beberapa komunitas ilmuan tentang gejalagejala dengan pendekatan fragmentarisme yang cenderung terspesialisasi berdasarkan langkah-langkah ilmiah menurut bidangnya masing-masing.

Dari uraian di atas, dapat disimpulkan paradigma berarti kumpulan tata nilai yang membentuk pola pikir seseorang sebagai titik tolak pandangannya. Sehingga akan membentuk citra subjektif seseorang mengenai realita dan akhirnya akan menentukan bagaimana seseorang menanggapi realita itu.

Selain dikaji mengenai konsep paradigma, dibahas juga mengenai defenisi integralistik. Pengertian integralistik menurut Kamus Besar Bahasa Indonesia merupakan satu keseluruhan. Sedangkan menurut Soepomo, integralistik adalah dimana semua kelompok sosial dan individu secara organis terkait satu dengan yang lainnya secara menyeluruh.

Bila konsep integralistik dilihat dalam konteks kehidupan umat beragama di Indoensia, berakar pada keanekaragaman budaya bangsa. Pancasila sebagai asas kerohanian bangsa dan negara Indonesia pada hakikatnya merupakan suatu asas kebersaman, asas kekeluargaan serta religius. Dalam pengertian inilah maka bangsa Indonesia dengan keaneka-ragamannya membentuk suatu kesatuan yang integral, yang disebut Negara Indonesia sebagai suatu bangsa yang merdeka. Bangsa Indonesia yang membentuk suatu persekutuan hidup dengan mempersatukan keaneka-ragaman yang dimilikinya dalam satu kesatuan yang integral. Melalui sidang BPUPKI tanggal 31 Mei 1945. Supomo mengusulkan paham integralistik yang menurutnya paham ini berakar pada keanekaragaman budaya bangsa, namun

Intizar, Volume 23, Nomor 1, 2017 
Muhammad Noupal dan Erina Pane Paradigma Integralistik dan Toleransi Umat Beragama di Kota Palembang

hal itu justru mempersatukan dalam suatu kesatuan integral yang disebut Negara Indonesia.

Bangsa Indonesia pada hakikatnya merupakan suatu penjelmaan dari sifat kodrat manusia sebagai makhluk individu dan makhluk sosial. Dalam pengertian yang demikian ini maka manusia pada hakikatnya merupakan manusia yang saling bergantung antara satu sama lain. Sehingga hakikat manusia itu bukanah total individu dan juga bukanlah makhluk total sosial. Relasi yang saling bergantungan tersebut menunjukan bahwa manusia adalah merupakan suatu totalitas makhluk individu dan makhluk sosial. Adapun penjelmaan dalam wujud persekutuan hidup bersama adalah terwujud dalam suatu bangsa yang memiliki kesatuan yang integralistik.

Dalam pengertian ini, paham integralistik memberikan suatu prinsip bahwa negara adalah suatu kesatuan yang integral dari unsur-unsur yang menyusunnya, negara mengatasi semua golongan bagian-bagian yang membentuk negara, negara tidak memihak pada suatu golongan betapapun golongan tersebut sebagai golongan terbesar. Negara dan bangsa adalah untuk semua unsur yang membentuk kesatuan tersebut.

Dalam hubungan dengan masyarakat, maka paham integralistik menggambarkan suatu masyarakat sebagai suatu kesatuan organis yang integral yang setiap anggota, bagian, lapisan, kelompok, golongan yang ada di dalamnya, satu sama lain saling berhubungan erat dan merupakan satu kesatuan yang hidup. Eksistensi setiap unsur hanya berarti dalam hubungannya dengan keseluruhan, setiap anggota, bagian, lapisan, kelompok dan golongan dalam masyarakat itu memiliki tempat, fungsi, dan kedudukan masing- masing yang di akui, di hormati dan dihargai. Paham ini beranggapan bahwa setiap unsur merasa berkewajiban akan terciptanya keselamatan, kesejahteraan dan kebahagiaan bersama.

Paham integralistik yang terkandung dalam Pancasila meletakkan asas kebersamaan hidup, mendambakan keselarasan dalam hubungan antar individu maupun masyarakat. Dalam pengertian ini paham negara integralistik tidak memihak kepada yang kuat, tidak mengenal dominasi mayoritas dan juga tidak mengenal tirani minoritas. Maka, di dalamnya terkandung nilai kebersamaan, kekeluargaan, ke "binneka tunggal ika" an, nilai religiusitas serta selaras.

Paradigma integralistik dalam konteks kajian toleransi umat beragama, dimaknai sebagai paham dan konsep hubungan antar umat beragama yang toleran. Dalam paradigma integralistik, upaya mewujudkan toleransi umat beragama memerlukan kerjasama dan peran dari semua pihak, termasuk pemerintah dan tokoh agama. Hal ini karena, agama dan Negara merupakan suatu kesatuan yang tidak dapat tidak dipisahkan. Keduanya merupakan dua lembaga yang menyatu (interated). Ini juga memberikan pengertian bahwa Negara merupakan suatu lembaga politik dan sekaligus lembaga agama. Konsep ini menegaskan kembali 
bahwa Islam tidak mengenal pemisahan antara agama dan politik atau Negara. Konsep seperti ini sama dengan konsep teokrasi.

Paradigma ini kemudian melahirkan konsep tentang agama-negara. Yang berarti bahwa kehidupan kenegaraan diatur dengan menggunakan hukum dan prinsip keagamaan. Dari sinilah kemudian paradigma integralistik dikenal juga dengan paham Islam: din wa dawlah. Yang sumber positifnya adalah hukum agama. Paradigma integralistik ini anatara lain dianut oleh kelompok Islam Syi'ah. Hanya saja Syi'ah tidak menggunakan term dawlah tetapi dengan term imamah.

\section{Aspek-Aspek Paradigma Integralistik dalam Membangun Toleransi Umat Beragama}

Toleransi umat beragama dibangun dalam beberapa aspek paradigma integralistik. Aspek-aspek tersebut yakni: pertama, toleransi dalam aspek ekonomi. Toleransi umat beragama yang diharapkan adalah saling mengerti antar para pemeluk agama. Dalam arti saling memahami keadaan antar umat beragama baik masalah-masalah sosial masyarakat (RI, hal. 8). Dengan adanya rasa saling memahami dalam berinteraksi akan timbul sikap saling tolong menolong dalam kegiatan perekonomian. Hal ini tidak hanya timbul sikap saling tolong menolong, melainkan juga sikap saling menghormati dan saling menghargai dalam aktivitas perekonomian dan peribadatan.

Kedua, toleransi dalam aspek budaya. Penduduk Palembang merupakan etnis melayu dan menggunakan bahasa melayu yang telah disesuaikan dengan dialek setempat yang kini dikenal sebagai bahasa Palembang. Namun para pendatang seringkali menggunakan bahasa daerahnya sebagai bahasa sehari-hari, seperti bahasa Komering, Rawas, Musi dan Lahat. Pendatang dari luar Sumatera Selatan kadang-kadang juga menggunakan bahasa daerahnya sebagai bahasa seharihari dalam keluarga atau komunitas kedaerahan. Namun untuk berkomunikasi dengan warga Palembang lain. Penduduk asli umumnya menggunakan bahasa Palembang sebagai bahasa pengantar sehari-hari. Selain penduduk asli, di Palembang terdapat pula warga pendatang dan warga keturunan, seperti dari Jawa, Minangkabau, Madura, Bugis dan Banjar. Warga keturunan yang banyak tinggal di Palembang adalah Tionghoa, Arab dan India. Kota Palembang memiliki beberapa wilayah yang menjadi ciri khas dari suatu komunitas seperti Kampung Kapitan yang merupakan wilayah Komunitas Tionghoa serta Kampung Al Munawwar, Kampung Assegaf, Kampung Al Habsyi, Kuto Batu, 19 Ilir Kampung Jamalullail dan Kampung Alawiyyin Sungai Bayas 10 Ilir yang merupakan wilayah Komunitas Arab. Agama mayoritas di Palembang adalah Islam. Selain itu terdapat pula penganut Katolik, Protestan, Hindu, Buddha dan Konghucu (Laksono, 2016).

Dengan demikian bahwa Kota Palembang bukan hanya beragam agama namun juga beragam budaya. Maka dengan itu, perlunya mewujudkan toleransi dalam berbudaya. Seperti halnya kebebasan dan menghormati setiap agama 
Muhammad Noupal dan Erina Pane Paradigma Integralistik dan Toleransi Umat Beragama di Kota Palembang

merayakan atau menyelenggarakan segala sesuatu yang berhubungan dengan seni budaya yang bersumber dari tradisi dan kepercayaan agama masing-masing. Misalnya, adanya acara barongsai dari agama Budha, Maulid Nabi dari umat Islam, dan lain-lain.

Ketiga, toleransi dalam aspek sosial keagamaan. Toleransi beragama adalah sikap sabar dan menahan diri untuk tidak mengganggu dan tidak melecehkan agama atau sistem keyakinan dan ibadah penganut agama-agama lain. Kebebasan beragama pada hakikatnya adalah dasar bagi terciptanya kerukunan antar umat beragama. Tanpa kebebasan beragama tidak mungkin ada kerukunan antar umat beragama. Kebebasan beragama adalah hak setiap manusia. Hak untuk menyembah Tuhan diberikan oleh Tuhan, dan tidak ada seorang pun yang boleh mencabutnya.

Demikian juga sebaliknya, toleransi antarumat beragama adalah cara agar kebebasan beragama dapat terlindungi dengan baik. Kebebasan dan toleransi tidak dapat diabaikan. Namun yang sering kali terjadi adalah penekanan dari salah satunya, misalnya penekanan kebebasan yang mengabaikan toleransi dan usaha untuk merukunkan dengan memaksakan toleransi dengan membelenggu kebebasan. Untuk dapat mempersandingkan keduanya, pemahaman yang benar mengenai kebebasan beragama dan toleransi antar umat beragama merupakan sesuatu yang penting dalam kehidupan sehari-hari dalam bermasyarakat.

Berdasarkan pengertian toleransi, toleransi mengarah kepada sikap terbuka dan mau mengakui adanya berbagai macam perbedaan, baik dari sisi suku bangsa, warna kulit, bahasa, adat-istiadat, budaya, bahasa, serta agama. Ini semua merupakan fitrah dan sunnatullah yang sudah menjadi ketetapan Tuhan. Landasan dasar pemikiran ini adalah firman Allah dalam Qur'an surat Al-Hujurat ayat 13. Toleransi dalam beragama bukan berarti bebas mengikuti ibadah dan ritualitas semua agama tanpa adanya peraturan yang mengikat. Akan tetapi, toleransi beragama harus dipahami sebagai bentuk pengakuan akan adanya agama-agama lain. Selain itu, adanya kebebasan untuk menjalankan keyakinan agama masingmasing.

Konsep toleransi yang ditawarkan Islam sangatlah rasional dan praktis serta tidak berbelit-belit. Namun, dalam hubungannya dengan keyakinan (akidah) dan ibadah, umat Islam tidak mengenal kata kompromi. Ini berarti keyakinan umat Islam kepada Allah tidak sama dengan keyakinan para penganut agama lain terhadap tuhan-tuhan mereka. Demikian juga dengan tata cara ibadahnya. Bahkan Islam melarang penganutnya mencela tuhan-tuhan dalam agama manapun. Maka kata tasamuh atau toleransi dalam Islam bukanlah "barang baru", tetapi sudah diaplikasikan dalam kehidupan sejak agama Islam itu lahir.

Karena itu, agama Islam menurut hadits yang diriwayatkan oleh Bukhari, Rasulullah saw. pernah ditanya tentang agama yang paling dicintai oleh Allah, maka beliau menjawab: al-Hanafiyyah as-Samhah (agama yang lurus yang penuh toleransi), itulah agama Islam.

Intizar, Vol. 23, No. 1, 2017 
p-ISSN: 1412-1697; e-ISSN: 2477-3816

http://jurnal.radenfatah.ac.id/index.php/intizar

Toleransi sendiri terbagi atas tiga yaitu: pertama, negatif. Isi ajaran dan penganutnya tidak dihargai. Isi ajaran dan penganutnya hanya dibiarkan saja karena menguntungkan dalam keadaan terpaksa.Contoh PKI atau orang-orang yang beraliran komunis di Indonesia pada zaman Indonesia baru merdeka. Kedua, Isi ajaran ditolak, tetapi penganutnya diterima serta dihargai.Contoh Anda beragama Islam wajib hukumnya menolak ajaran agama lain didasari oleh keyakinan pada ajaran agama Anda, tetapi penganutnya atau manusianya Anda hargai. Ketiga, ekumenis. Isi ajaran serta penganutnya dihargai, karena dalam ajaran mereka itu terdapat unsur-unsur kebenaran yang berguna untuk memperdalam pendirian dan kepercayaan sendiri. Contoh Anda dengan teman Anda sama-sama beragama Islam atau Kristen tetapi berbeda aliran atau paham. Dalam kehidupan beragama sikap toleransi ini sangatlah dibutuhkan, karena dengan sikap toleransi ini kehidupan antar umat beragama dapat tetap berlangsung dengan tetap saling menghargai dan memelihara hak dan kewajiban masing-masing.

Islam adalah agama yang toleran, agama yang penuh kasih sayang yang selalu menghormati antar umat beragama. Bukankah dalam Al-Quran dikatakan bahwa "Bagiku agamaku dan bagimu agamamu" (QS.Al-kafirun: 6) bukankah itu adalah salah satu pengakuan Islam terhadap keberagaman agama, bahkan Rasulullah sendiri mencontohkan ketika Rasul berzakat dia juga memberikan Zakatnya kepada orang yahudi, ketika ditanya orang yahudi mengapa Rasulullah memberi zakat kepadanya padahal dia bukan seorang muslim, Jawab beliau "Engkau adalah tetanggaku, dan aku wajib memuliakan Saling Menghormati Sesama".

Sebagai makhluk sosial manusia mutlak membutuhkan sesamanya dan lingkungan sekitar untuk melestarikan eksistensinya di dunia. Tidak ada satu pun manusia yang mampu bertahan hidup dengan tanpa memperoleh bantuan dari lingkungan dan sesamanya.

Dalam konteks ini, manusia harus selalu menjaga hubungan antar sesama dengan sebaik-baiknya, tak terkecuali terhadap orang lain yang tidak seagama, atau yang lazim disebut dengan istilah toleransi beragama. Toleransi beragama berarti saling menghormati dan berlapang dada terhadap pemeluk agama lain, tidak memaksa mereka mengikuti agamanya dan tidak mencampuri urusan agama masing-masing. Ummat Islam diperbolehkan bekerja sama dengan pemeluk agama lain dalam aspek ekonomi, sosial dan urusan duniawi lainnya.

Dalam sejarah pun, Nabi Muhammad Saw telah memberi teladan mengenai bagaimana hidup bersama dalam keberagaman. Teladan itu antara lain: tidak ada paksaan dalam beragama, Dalam soal beragama, Islam tidak mengenal konsep pemaksaan beragama. Setiap diri individu diberi kelonggaran sepenuhnya untuk memeluk agama tertentu dengan kesadarannya sendiri, tanpa intimidasi. Di dalam al-Quran pun dijelaskan: (QS. Yunus; 99-100) dan juga (QS. Al Kahfi; 29). Persoalan keyakinan atau beragama adalah terpulang kepada hak pilih orang per

Intizar, Volume 23, Nomor 1, 2017 
orang, masing-masing individu, sebab Allah Subhanahu wata'ala sendiri telah memberikan kebebasan kepada manusia untuk memilih jalan hidupnya. Manusia oleh Allah Subhanahu wata'ala diberi peluang untuk menimbang secara bijak dan kritis antara memilih Islam atau kufur dengan segala resikonya. Meski demikian, Islam tidak kurang-kurangnya memberi peringatan dan menyampaikan ajakan agar manusia itu mau beriman.

Selain itu, Nabi Muhammad juga mengajarkan bahwa dalam hal aqidah tidak ada toleransi. Jika dalam aspek sosial kemasyarakatan semangat toleransi menjadi sebuah anjuran, ummat Islam boleh saling tolong menolong, bekerja sama dan saling menghormati dengan orang-orang non Islam, tetapi dalam soal aqidah sama sekali tidak dibenarkan adanya toleransi antara ummat Islam dengan orangorang non Islam.

Rasulullah Shollallahu alaihi wasallam tatkala diajak ber-toleransi dalam masalah aqidah, bahwa pihak kaum Muslimin mengikuti ibadah orang-orang kafir dan sebaliknya, orang-orang kafir juga mengikuti ibadah kaum Muslimin, secara tegas Rasulullah diperintahkan oleh Allah Subhanahu wata'ala untuk menolak tawaran yang ingin menghancurkan prinsip dasar Aqidah Islamiyah itu. Allah Ta'ala berfirman: Katakanlah: "Hai orang-orang kafir. Aku tidak akan menyembah apa yang kamu sembah. Dan kamu bukan penyembah Tuhan yang Aku sembah. Dan Aku tidak pernah menjadi penyembah apa yang kamu sembah, Dan kamu tidak pernah (pula) menjadi penyembah Tuhan yang Aku sembah. Untukmu agamamu, dan untukkulah, agamaku." (QS.al-kaffirun: 1-6)

Dalam setiap melaksanakan sholat, sebenarnya ummat Islam telah diajarkan untuk selalu berpegang teguh terhadap aqidah Islamiyah dan jangan sampai keyakinan ummat Islam itu sedikit pun dirasuki oleh virus syirik, yaitu dengan membaca: "Sesungguhnya Aku menghadapkan diriku kepada Rabb yang menciptakan langit dan bumi, dengan cenderung kepada agama yang benar, dan Aku bukanlah termasuk orang-orang yang mempersekutukan Tuhan. Sesungguhnya sholatku, ibadahku, hidupku dan matiku hanya milik Allah, Tuhan semesta alam. Tidak ada yang menyekutui-Nya." (Q.S.Ali Imran: 85)

Siapa yang menginginkan kebahagiaan dan kemuliaan di dunia dan akhirat, tidak ada jalan kecuali beriman kepada Allah Subhanahu wata'ala dan beribadah kepada-Nya. Kemuliaan itu tidak bisa dicapai dengan menyembah selain Allah Ta'ala. Kemuliaan hanya milik Allah semata. "Barangsiapa yang menghendaki kemuliaan, maka bagi Allah-lah kemuliaan itu semuanya. Kepada-Nyalah naik perkataan-perkataan yang baik dan amal yang saleh dinaikkan-Nya. Dan orangorang yang merencanakan kejahatan bagi mereka azab yang keras, dan rencana jahat mereka akan hancur." 
p-ISSN: 1412-1697; e-ISSN: 2477-3816

http://jurnal.radenfatah.ac.id/index.php/intizar

\section{Peran Pemerintah-Ulama dalam Membangun Toleransi Umat Beragama Melalui Paradigma Integralistik}

Sebelum mengkaji tentang peran pemerintah dalam membangun toleransi umat beragama melalui paradigma integralistik, akan dijelaskan terlebih dahulu makna toleransi umat beragama. Toleransi umat beragama dimaknai sebagai pemberian kebebasan pada sesama manusia atau kepada sesama warga masyarakat untuk menjalankan keyakinannya atau mengatur hidupnya dan menentukan nasibnya masing-masing, selama di dalam menjalankan dan menentukan tidak bertentangan dengan syarat-syarat atas terciptanya ketertiban dan perdamaian dalam masyarakat (Hasyim, 1979, hal. 22). Toleransi juga dapat diartikan sebagai suatu sikap atau sifat dari seseorang untuk membiarkan kebebasan kepada orang lain serta memberikan kebenaran atas perbedaan tersebut sebagai pengakuan hak-hak asasi manusia.

Pelaksanaan sikap toleransi ini harus didasari sikap kelapangan dada terhadap orang lain dengan berpedoman kepada prinsip-prinsip yang dipegang sendiri, yakni tanpa mengorbankan prinsip-prinsip tersebut (Ali, 1989, hal. 80). Hal ini memperjelas bahwa toleransi terjadi dan berlaku karena terdapat perbedaan prinsip, dan menghormati perbedaan atau prinsip orang lain tanpa mengorbankan prinsip sendiri (Al-Munawar, 2005, hal. 13). Dengan kata lain, pelaksanaannya hanya pada aspek yang detail dan teknis bukan dalam persoalan yang prinsipil.

Pemerintah mempunyai peran dan tanggung jawab dalam terwujud dan terbinanya kerukunan hidup umat beragama. Hal ini menunjukkan bahwa kualitas umat beragama di Indonesia belum berfungsi seperti seharusnya, yang diajarkan oleh agama masing-masing. Sehingga ada kemungkinan timbul konflik di antara umat beragama. Oleh karena itu dalam hal ini, pemerintah sebagai pelayan, mediator atau fasilitator merupakan salah satu elemen yang dapat menentukan kualitas atau persoalan umat beragama tersebut.

Pada prinsipnya, umat beragama perlu dibina melalui pelayanan aparat pemerintah yang memiliki peran dan fungsi strategis dalam menentukan kualitas kehidupan umat beragama, melalui kebijakannya. Dalam rangka perwujudan dan pembinaan di tengah keberagaman agama budaya dan bangsa, maka Said Agil Husin Al Munawar mengungkapkan bahwa kerukunan umat beragama memiliki hubungan yang sangat erat dengan faktor ekonomi dan politik. Di samping faktorfaktor lain seperti penegakkan hukum, pelaksanaan prinsip-prinsip keadilan dalam masyarakat dan peletakkan sesuatu pada proporsinya. Dalam kaitan ini strategi yang perlu dilakukan, antara lain: pertama, memberdayakan institusi keagamaan. Artinya 
lembaga-lembaga keagamaan di daya gunakan secara maksimal. Sehingga akan mempercepat proses penyelesaian konflik antar umat beragama. Di samping itu, pemberdayaan tersebut dimaksudkan untuk lebih memberikan bobot/warna tersendiri dalam menciptakan ukhuwah (persatuan dan kesatuan) yang hakiki, tentang tugas dan fungsi masing-masing lembaga keagamaan dalam masyarakat sebagai perekat kerukunan antar umat beragama.

Kedua, membimbing umat beragama agar makin meningkat keimanan dan ketakwaan mereka kepada Tuhan Yang Maha Esa, dalam suasana rukun baik intern maupun antar umat beragama. Ketiga, melayani dan menyediakan kemudahan bagi para penganut agama. Keempat, tidak mencampuri urusan akidah/dogma dan ibadah sesuatu agama. Kelima, mendorong peningkatan pengamalan dan penuaian ajaran agama. Keenam, melindungi agama dari penyalahgunaan dan penodaan. Ketujuh, mendorong dan mengarahkan seluruh umat beragama untuk hidup rukun dalam bingkai Pancasila dan konstitusi dalam tertib hukum bersama. Kedelapan, mendorong, memfasilitasi dan mengembangkan terciptanya dialog dan kerjasama antara pimpinan majelis-majelis, dan organisasi-organisasi keagamaan dalam rangka untuk membangun toleransi dan kerukunan antar umat beragama.

Kesembilan, mengembangkan wawasan multikultural bagi segenap lapisan dan unsur masyarakat melalui jalur pendidikan, penyuluhan dan riset aksi. Kesepuluh, meningkatkan pemberdayaan sumber daya manusia (pemimpin agama dan pemimpin masyarakat lokal) untuk ketahanan dan kerukunan masyarakat bawah. Kesebelas, fungsionalisasi pranata lokal, seperti adat istiadat, tradisi dan norma-norma sosial yang mendukung upaya kerukunan umat beragama. Keduabelas, mengundang partisipasi semua kelompok dan lapisan masyarakat agama sesuai dengan potensi yang dimiliki masing-masing, melalui kegiatankegiatan dialog, musyawarah, tatap muka, kerjasama sosial dan sebagainya.

Ketigabelas, bersama-sama para pemimpin majelis-majelis agama, seperti Majelis Ulama Indonesia (MUI), Persekutuan Gereja-gereja di Indonesia (PGI), Konfrensi Wali Gereja Indonesia (KWI), Parishada Hindhu Dharma Indonesia (PHDI), dan Perwakilan Umat Budha Indonesia (WALUBI), Majelis Tinggi Agama Khonghuchu Indonesia (MATAKIN), Departemen agama melalui Badan Litbang Agama dan Diklat Keagamaan melakukan kunjungan bersama-bersama ke berbagai daerah dalam rangka berdialog dengan umat di lapisan bawah dan memberikan pengertian tentang pentingnya membina dan mengembangkan kerukunan umat beragama. Keempatbelas, melakukan mediasi bagai kelompok-kelompok masyarakat yang dilanda konflik, (misalnya; kasus Ambon dan Maluku Utara) 
p-ISSN: 1412-1697; e-ISSN: 2477-3816

http://jurnal.radenfatah.ac.id/index.php/intizar

dalam rangka untuk mencari solusi bagi tercapainya rekonsiliasi, sehingga konflik bisa diberhentikan dan tidak berulang di masa depan.

Kelimabelas, memberi sumbangan dana (sesuai dengan kemampuan), kepada kelompok-kelompok masyarakat yang terpaksa mengungsi dari daerah asal mereka, karena dilanda konflik sosial dan etnis yang dirasakan pula bernuansakan keagamaan. Keenambelas, membangun kembali sarana-sarana ibadah (Gereja dan Mesjid) yang rusak di daerah-daerah yang masyarakatnya terlibat konflik, sehingga mereka dapat mefungsikan kembali rumah-ruumah ibadah tersebut.

Sedangkan peran pemerintah Kota Palembang dan ulama lebih bersifat hubungan kerjasama dalam mewujudkan sikap toleran umat beragama yang ada di Kota Palembang. Masyarakat menjadikan tokoh agama/ ulama sebagai figur yang mampu berpartisipasi dalam menjaga kerukunan. Tokoh-tokoh agama berinteraksi saat perayaan hari raya, saling membantu tokoh agama lain, pekerjaan, pemimpin spiritual, memberi kebebasan interen, memberi kebebasan eksteren. Hak dan kewajiban dalam mejalankan fungsi sebagai tokoh agama dapat berjalan dengan baik jika tokoh agama mengerti perannya.

Dari uraian di atas dapat dipahami, bahwa untuk menciptakan dan memelihara kerukunan umat beragama, diperlukan upaya dan usaha yang sungguh-sungguh dan dibutuhkan kerja sama dari semua pihak baik dari umat beragama itu sendiri, pemuka agama serta pemerintah yang berwenang. Pemerintah sebagai pihak yang berwenang melalui Menteri Agama dan Menteri Dalam Negeri telah mengeluarkan "Peraturan Bersama No. 9 dan No. 8 Tahun 2006 tentang pedoman pelaksanaan tugas kepala daerah dalam pemeliharaan kerukunan umat beragama, pemberdayaan Forum Kerukunan Umat Beragama (FKUB), dan pendirian rumah ibadah. Peraturan bersama ini telah ditanda tangani dan disahkan pada tanggal 21 Maret 2006".

Salah satu point dari peraturan bersama itu adalah pemberdayaan Forum Kerukunan Umat Beragama (FKUB). Melihat program kerja yang menjadi agenda kerja Forum Kerukunan Umat Beragama (FKUB), maka semua upaya yang menyangkut kerukunan umat beragama sudah terangkum dalam program kerja Forum Kerukunan Umat Beragama (FKUB). Dengan demikian melalui Forum Kerukunan Umat Beragama (FKUB) ini diharapkan akan tercipta keamanan dan ketertiban antar umat beragama, ketentraman dan kenyamanan di lingkungan masyarakat berbangsa dan bernegara.

Dalam rangka mewujudkan kerukunan hidup umat beragama agar senantiasa tetap terpelihara, maka masing-masing pihak baik dari umat beragama, tokoh agama/pemuka agama, maupun pemerintah setempat harus memperhatikan upaya-upaya yang harus dilakukan demi terwujudnya kerukunan hidup umat beragama.

Intizar, Volume 23, Nomor 1, 2017 
Upaya yang mendorong terjadinya kerukunan umat beragama, yakni: pertama, memperkuat dasar-dasar kerukunan internal dan antar umat beragama, serta antar umat beragama dengan pemerintah. Kedua, membangun harmoni sosial dan persatuan nasional, dalam bentuk upaya mendorong dan mengarahkan seluruh umat beragama untuk hidup rukun dalam bingkai teologi dan implementasi dalam menciptakan kebersamaan dan sikap toleransi. Ketiga, menciptakan suasana kehidupan beragama yang kondusif, dalam rangka memantapkan pendalaman dan penghayatan agama serta pengamalan agama, yang mendukung bagi pembinaan kerukunan hidup intern umat beragama dan antar umat beragama.

Keempat, melakukan eksplorasi secara luas tentang pentingnya nilai-nilai kemanusiaan dari seluruh keyakinan plural umat manusia, yang fungsinya dijadikan sebagai pedoman bersama dalam melaksanakan prinsip-prinsip berpolitik dan berinteraksi sosial satu sama lainnya dengan memperlihatkan adanya sikap keteladanan. Kelima, melakukan pendalaman nilai-nilai spiritual yang implementatif bagi kemanusiaan yang mengarahkan kepada nilai-nilai ketuhanan, agar tidak terjadi penyimpangan-penyimpangan nila-nilai sosial kemasyarakatan maupun sosial keagamaan. Keenam, menempatkan cinta dan kasih dalam kehidupan umat beragama dengan cara menghilangkan rasa saling curiga terhadap pemeluk agama lain, sehingga akan tercipta suasana kerukunan yang manusiawi tanpa dipengaruhi oleh faktor-faktor tertentu.

Ketujuh, menyadari bahwa perbedaan adalah suatu realita dalam kehidupan bermasyarakat, oleh sebab itu hendaknya hal ini dijadikan mozaik yang dapat memperindah fenomena kehidupan beragama.

Dalam upaya memantapkan kerukunan itu, hal serius yang harus diperhatikan adalah fungsi pemuka agama, tokoh masyarakat dan pemerintah. Dalam hal ini pemuka agama, tokoh masyarakat adalah figur yang dapat diteladani dan dapat membimbing, sehingga apa yang diperbuat mereka akan dipercayai dan diikuti secara taat. Selain itu mereka sangat berperan dalam membina umat beragama dengan pengetahuan dan wawasannya dalam pengetahuan agama.

\section{Implementasi Kebijakan Pemerintah dalam Membangun Toleransi antar Umat Beragama}

Implementasi kebijakan pemerintah kota Palembang dalam membangun toleransi umat beragama di kota ini tertuangkan dalam faktor pendukung program kerja, yakni membangun solidaritas umat beragama yang kuat, umat Islam sebagai mayoritas di Kota Palembang, kuantitas konflik yang sedikit, adanya alokasi dana anggaran. Keempat poin di atas merupakan faktor pendukung program kerja yang dilakukan pemerintah Kota Palembang untuk mewujudkan toleransi umat beragama di Kota Palembang yang diuraikan dalam penjelasan sebagai berikut: pertama,

Intizar, Vol. 23, No. 1, 2017 
p-ISSN: 1412-1697; e-ISSN: 2477-3816

http://jurnal.radenfatah.ac.id/index.php/intizar

solidaritas umat beragama yang kuat. Setiap manusia sebagai ciptaan Tuhan yang hidup di dunia ini selalu mendambakan kerukunan dan perdamaian, demikian pula umat beragama di Kota Palembang. Bukan saja bagi diri atau kelompoknya tetapi bagi keseluhuran warga negara, bahkan seluruh penduduk dan lingkungannya.

Sejauh ini, kerukunan antar umat beragama di Kota Palembang sampai saat ini berjalan dengan kondusif. Hal ini didasarkan pada kebutuhan sosial dimana satu sama lain saling membutuhkan agar kebutuhan-kebutuhan hidup dapat terpenuhi. Kerukunan antar umat manusia pada umumnya baik seagama maupun luar agama dapat diwujudkan apabila satu sama lain dapat saling menghormati dan menghargai. Hal inilah yang dirasakan masyarakat beragama di Kota Palembang sampai saat ini.

Kenyataan ini didukung oleh kesadaran masyarakat Kota Palembang untuk menjaga kerukunan umat beragama. Sehingga ketika ada perselisihan baik disebabkan karena persoalan pribadi yang terkadang kemudian menjadi persoalan etnis dari pihak pemerintah, tokoh agama, dan tokoh etnis cepat meredamnya.

Meskipun pemerintah bertanggung jawab penuh terhadap kerukunan umat beragama. Namun bagi pemerintah Kota Palembang tumbuhnya solidaritas yang kuat dari masyarakat Kota Palembang sangat menjadi prioritas demi terwujudnya serta terpeliharanya kerukunan umat beragama di Kota Palembang.

Tumbuhnya solidaritas yang kuat dari umat beragama merupakan menjadi prioritas dan pendukung demi terciptanya kerukunan umat beragama. Demikian pula suasana umat beragama di Kota Palembang saat ini yang senantiasa menjaga hubungan harmonis di antara umat beragama dan memiliki rasa solidaritas yang tinggi. Karena kerukunan umat beragama dapat terwujud apabila dilandasi hubungan sesama umat beragama yang toleransi, saling pengertian, saling menghormati, saling menghargai dalam kesetaraan pengamalan ajaran agama dan kerja sama dalam kehidupan masyarakat dan bernegara.

Kedua, umat Islam sebagai mayoritas. Kota Palembang identik dengan lebih dari satu umat beragama dan penduduk Kota Palembang mayoritas penduduknya beragama Islam. Oleh karena itu, salah satu faktor pendukung dari program yang dilakukan pemerintah Kota Palembang demi terciptanya kerukunan umat beragama. Salah satunya karena kerukunan antar umat islam yang didasarkan pada akidah islamnya, serta pemenuhan kebutuhan sosial yang digambarkan bagaikan satu bangunan. Dimana umat islam satu sama lain saling menguatkan dan juga digambarkan seperti satu tubuh. Jika ada bagian tubuh yang sakit maka seluruh anggota tubuh merasakan sakit. Dari dasar pemahaman inilah dapat mendukung program yang dilakukan pemerintah Kota Palembang untuk mewujudkan kerukunan umat beragama di Kota Palembang.

Dengan begitu, umat Islam di Kota Palembang yang juga termasuk sebagai salah satu faktor pendukung dari program kerja yang dilakukan oleh pemerintah Kota Palembang dalam menciptakan kerukunan umat beragama. Hal itu diperkuat, 
dengan adanya ajaran dalam Islam bahwa seorang muslim tidak diperbolehkan merendahkan diri sendiri apalagi merendahkan orang lain. Demikian pula merendahkan Tuhan atau peribadatan agama lain. Sehingga pemeluk agama lain pun menghargai dan menghormati agama Islam. Dengan demikian tidak akan terjadi konflik di antara umat beragama.

Ketiga, kuantitas konflik yang sedikit. Saat ini, ini nilai-nilai kerukunan yang dijaga dengan baik oleh masyarakat mulai terkikis, semboyan Bhineka Tunggal Ika sudah mulai luntur dalam pemahaman dan pengamalan masyarakat. Ini bisa dilihat berbagai konflik yang terjadi diberbagai daerah seperti kasus Poso, Ambon, Sampang yang mengatasnamakan agama yang berlindung dibalik simbol agama dan baru baru ini kasu bom bunur di Solo. Konflik-konflik yang mengatasnamakan agama ini seringkali menimbulkan terjadinya disintegrasi (perpecahan) bangsa. Akan tetapi seiring dengan keadaaan kerukunan umat beragama seperti di atas. Patut disadari bahwa kondisi masyarakat yang majemuk kapan saja dapat memicu terjadinya konflik.

Kota Palembang sebagai kota yang identik dengan keanekaragaman agama dan budaya dapat dilihat kuantitas konflik umat beragamanya sangat sedikit sekali bahkan tidak terjadi konflik sama sekali. Hal ini berbagai upaya dan peran pemerintah Kota Palembang telah dilakukan demi terwujudnya serta terpelihara kerukunan umat beragama. Untuk itu perlu senantiasa dibangun, dipertahankan, diperkuat dan dilestarikan serta dipelihara kerukunan umat beragama dengan berupaya melakukan beberapa program atau agenda penting seperti yang telah dilakukan oleh pemerintaah Kota Palembang.

Kerukunan umat beragama di Kota Palembang hingga saat ini berjalan dengan kondusif, rukun, dan damai. Hal ini disebabkan karena peran dan upaya yang telah dilakukan oleh pemerintah Kota Palembang demi menciptakan kerukunan umat beragama pada masyarakat Kota Palembang dapat dikatakan sangat maksimal.

Salah satu kegiatan yang dilakukan untuk mewujudkan sikap yang toleran antar umat beragama, yakni: pada hari senin tanggal 11 Agustus 2016 pemerintah Kota Palembang menggelar Halal Bihalal. Kegiatan ini dilakukan untuk lebih mempererat kerukunan dan kebersamaan antar sesama umat beragama yang ada di Palembang. Kegiatan Halal Bihalal ini dilaksanakan di Rumah Dinas Walikota Palembang bersama jajaran PNS Pemkot Palembang. Kegiatan halal bihalal ini menjadi momentum yang baik untuk bersilaturahmi sesama umat. Palembang merupakan tempat tinggal dan pertemuan berbagai suku, agama dan ras, dari situlah tumbuh rasa kebersamaan antar sesama masyarakat (Sumsel, 2016).

Selain itu, Kepala Kantor Wilayah Kementerian Agama Provinsi Sumatera Selatan (Kakanwil Kemenag Sumsel) Drs. Hambali M.Si juga mengadakan silaturahim tokoh lintas agama, di Kanwil Kemenag Jalan Ade Irma Nasution, hari Senin 1 Agustus 2016. Acara yang dihadiri oleh tokoh lintas agama serta Forum 
p-ISSN: 1412-1697; e-ISSN: 2477-3816

http://jurnal.radenfatah.ac.id/index.php/intizar

Komunikasi Umat Beragama (FKUB) baik provinsi Sumsel ataupun Kota Palembang. Hambali mengatakan, ini merupakan aksi dari Kanwil Kemenag menyikapi kejadian di Tanjung Balai. Kejadian dimana saja membangunkan dari kekondusipan kerukunan umat beragama. "Kegiatan ini akan rutin kita lakukan, tidak seperti pemadam kebakaran yang memadamkan api bila kebakaran tetapi kita cegah sejak awal dari awal dari mana api berasal," katanya. Hambali berharap, di kabupaten/kota juga melakukan hal yang sama, agar tidak ada kejadian lagi seperti di Tanjung Balai (Palembang, 2016).

Sehingga program kerja untuk mewujudkan sikap yang toleran antar umat beragama, yang kemudian tercipannya kerukunan umat beragama di Kota Palembang berjalan dengan lancar sesuai dengan rencana pemerintah Kota Palembang. Didukung kondisi masyarakat Palembang yang mempunyai rasa solidaritas yang kuat sehingga kuantitas konflik sedikit. Meskipun Kota Palembang identik dengan kota yang beranekaragam agama dan budaya namun umat beragama di Kota Palembang tetap rukun dan harmonis.

Keempat, adanya alokasi dana anggaran. Salah satu faktor pendukung program kerja pemerintah Kota Palembang untuk mewujudkan kerukunan umat beragama adalah adanya alokasi dana anggaran. Pemeliharaan kerukunan umat beragama adalah upaya bersama umat beragama dan pemerintah di bidang pelayanan, pengaturan, dan pemberdayaan umat beragama. Oleh karena itu, segala sesuatu yang berhubungan dengan masalah anggaran kerukunan umat beragama semua ditanggung oleh beban anggaran pendapatan dan belanja negara.

\section{Model Toleransi Umat Beragama Perspektif Paradigma Integralistik}

Salah satu model toleransi umat beragama yang dilakukakan pemerintah Kota Palembang, yakni diadakannya berbagai kegiatan yang bertujuan untuk memperkuat sikap toleransi antar umat beragama. Kegiatan tersebut diantara nya Kodam II/Sriwijaya menggelar Komunikasi Sosial dan Silaturahmi dengan Forum Kerukunan Umat Beragama (FKUB) Sumsel, kegiatan ini bertempat di Gedung Sudirman Makodam II/Swj Jln. Jend. Sudirman Km. 2,5 Palembang, pada hari Rabu tanggal 22 juli 2015. Kegiatan ini bertujuan untuk menyikapi terjadinya insiden konflik, di Tolikara Papua yang bertepatan dengan hari raya Idul Fitri 1 Syawal 1436 Hijriah yang lalu agar tidak terulang kembali, tidak berkembang dan bertambah luas, termasuk di wilayah Sumbagsel.

Dalam acara ini hadir dalam acara tersebut, Wakil Gubernur Sumsel Bpk. Ishak Mekki beserta anggota FKPD Provinsi Sumsel, Wakapolda Sumsel Brigjen Pol Syaiful Zachri, Plt. Walikota Palembang Bpk. Harnojoyo beserta anggota FKPD Kota Palembang, Ketua Forum Komunikasi Umat Beragama Provinsi Sumsel, beserta para Pengurus, Para koordinator perwakilan lintas agama.

Dikatakan Pangdam bahwa, sudah menjadi tugas dan kewajiban kita untuk memberikan pemahaman dan membentengi umat agar mampu menahan diri dan 
Muhammad Noupal dan Erina Pane Paradigma Integralistik dan Toleransi Umat Beragama di Kota Palembang

tidak terprovokasi. Forum-forum antar umat beragama dan kegiatan seperti ini perlu terus kita bangun, agar tidak terjadi miss komunikasi atau kesalahpahaman dikalangan umat dalam menyikapi situasi yang berkembang.

Oleh sebab itu sambung Pangdam, agar seluruh komponen bangsa, khususnya kalangan pemuka agama harus terus meningkatkan upaya-upaya untuk membangun kebersamaan, semangat persatuan dan kesatuan serta menggelorakan kembali kesadaran dan semangat toleransi, sikap saling menghormati, mengasihi dan menghargai dalam kemajemukan dan keberagaman.

Selain itu, FKUB juga mengadakan kegiatan pertemuan antara pemuka agama dari berbagai agama yang ada di Kota Palembang. Acara ini diadakan Senin tanggal 1 Agustus 2016 bertempat di Departemen Agama Provinsi Sumatera Selatan Jalan A. Rivai. Forum ini digelar demi menyikapi kejadian pembakaran rumah ibadah yang berlokasi di Tanjung Balai, Kabupaten Asahan Medan Sumatera Utara, pada hari Jum'at 29 Juli 2016. Kejadian yang diduga berawal dari pengaduan salah satu warga Tionghoa yang mengeluhkan atas suara adzan yang dikumandangkan di masjid itu. Hingga alasan yang belum jelas pada dini harinya terjadi kebakaran hebat yang menghanguskan lebih dari lima tempat ibadah Vihara.

Setelah pertemuan antara umat perwakilan umat muslim dan Budha di Palembang mengalami kesepakatan dan membuahkan tujuh hasil kesepakatan, yang isinya adalah sebagai berikut: pertama, berperan secara pro aktif dalam upaya menjaga stabilitas keamanan, ketertiban dan kerukunan antar umat beragama di Provinsi Sumatera Selatan. Kedua, menjadi contoh/teladan bagi seluruh jajaran, anggota, masyarakat dalam upaya menjaga kerukunan antar umat beragama di Provinsi Sumatera Selatan. Ketiga, bersama-sama menjaga sarana dan prasarana rumah ibadah dari gangguan pihak yang tidak bertannggung jawab di Provinsi Sumatera Selatan. Keempat, bersedia menjadi penyampai informasi dan mengajak seluruh jajaran/anggota/masyarakat mengenai arti pentingnya kerukunan dan kebersamaan antar umat beragama. Kelima, mendukung proses penegakan hukum dalam upaya menjaga stabilitas keamanan dan ketertiban di Provinsi Sumatera Selatan. Keenam, bersama-sama bertekad menjaga kondusifitas dan menolak segala bentuk anarkisme di Provinsi Sumatera Selatan. Ketujuh, sepakat mendukung implementasi layanan informasi kerukunan umat beragama berbasis informasi dan teknologi. Kesepakatan tersebbut disahkan oleh perwakilan umat muslim yang dalam hal ini diwakili oleh Ketua FKUB Sumsel Tohlon Abdulrauf dan perwakilan Majelis Budhayana Indonesia Sumsel Indra Lily. Dengan kesepakatan ini menjadi langkah awal kerukunan umat beragama untuk saling menjaga stabilitas di wilayah Sumsel.

Ada juga kegiatan yang diadakan oleh Humas Provinsi Sumatera Selatan yang diadakan di Hotel Budi Palembang pada tanggal 6 Juni 2016. Kegiatan ini diadakan dalam rangka menambah wawasan bagi pengurus Forum Kerukunan Umat Beragama (FKUB) Kabupaten/ Kota, baru-baru ini Kantor Kementrian Agama

Intizar, Vol. 23, No. 1, 2017 
Provinsi Sumatera Selatan. Kegiatan yang dibuka secara langsung oleh Kepala Kantor Wilayah Kemenag Provinsi Sumatera Selatan, Drs, H.Najib Haitami, MM diikuti sebanyak 40 peserta utusan FKUB Kabupaten/Kota 15 peserta, Kankemenag Kab/Kota 15 peserta dan selebihnya dari Kanwil Kemenag Sumsel 3 peserta serta dari MTs dan MI 7 peserta. Kegiatan ini sebagai ajang silaturrahim antar pengurus FKUB, juga sebagai sarana informasi, dan evaluasi terhadap berbagai problematika yang dihadapi Pengurus FKUB dalam melaksanakan tugas pokok, maupun tantangan yang ada dalam mensosialisasikan keberadaan Peraturan Bersama Menteri Agama dan Menteri Dalam Negeri Nomor 9 dan 8 tahun 2006 tentang Pedoman Pelaksanaan Tugas Kepala Daerah/ wakil kepala Daerah Dalam Pemeliharaan Kerukunan Umat Beragama, Pemberdayaan Forum Kerukunan Umat Beragama dan Pendirian Rumah Ibadah.Kepala Kantor Wilayah Kementerian Agama Provinsi Sumatera Selatan, Drs.H.Najib Haitami,MM dalam sambutannya mengatakan bahwa "FKUB merupakan mitra kerja Kementerian Agama, jadi kalau FKUB-nya tidak akur/rukun dengan Kementerian Agama. Maka, kerukunan dan kedamaian di Indonesia dapat terancam, karena tugas memelihara Kerukunan Umat Beragama merupakan tugas amat berat, sehingga bila dilakukan bersama-sama tentu akan terasa ringan. Oleh karena itu untuk merangsang dan menunjang kinerja FKUB di daerah, maka Kementerian Agama Provinsi Sumatera Selatan membantu dana operasional sebesar Dua Puluh Lima Juta Rupiah". Sedangkan Ketua Panitia, Saefuddin,S.Ag dalam laporannya mengharapkan agar para peserta workshop dapat mengikuti secara dengan seksama, karena tujuan diadakannya kegiatan ini untuk menyatukan misi,visi, budaya rukun damai untuk meredam konplik yang terjadi. Output kegiatan telah menghasilkan beberapa rekomendasi dari peserta yang diserahkan secara langsung kepada Kepala Kantor Wilayah Kemenag Sumsel pada waktu penutupan kegiatan (Sumsel K. , 2016).

Selain kegiatan pertemuan dengan pemuka agama dari beragam agama yang ada di Palembang. Pemerintah juga mengadakan workshop dengan tema "Penguatan Kapasitas Bagi Pemuka Agama dan Dewan FKUB berbasis Toleransi". Workshop ini diselenggarakan oleh The Wahid Institute (Jakarta) bekerjasama dengan Lembaga Kajian Hukum Islam (LKHI) Palembang, Sumatera Selatan. Dengan tema ini diharapkan dapat memperkuat pemahaman dan meningkatkan kesadaran para pemimpin agama tentang jaminan kebebasan beragama dan berkeyakinan di Indonesia agar bisa menghormati (to respect), melindungi (to protect), dan menjamin (to fulfill) sekaligus mengurangi rasa kecurigaan, prasangka, diskriminasi dan menemukan jalan untuk mewujudkan masyarakat Islam Indonesia, khususnya di Palembang yang cinta damai.

Kegiatan ini dimulai dari tanggal 24 Oktober sampai 26 Oktober 2009 bertempat di Hotel Swarnadwipa Jl. Tasik No. 2 Palembang. Kegiatan ini diadakan selama dua hari. Setiap hari ada 3 jenis aktifitas utama, yaitu: presentasi, dialog, dan FGD. Presentasi mengenai 3 level isu terkait dengan kebebasan beragama dan 
Muhammad Noupal dan Erina Pane Paradigma Integralistik dan Toleransi Umat Beragama di Kota Palembang

berkeyakinan, antara lain: regulasi keagamaan yang diskriminatif, peran negara dalam menjamin hak-hak Sipol, Jaminan Hak Sipol dalam Konstitusi dan ICCPR, dan beberapa tema lain terkait dengan beberapa isu sosial keagamaan disusul dengan tanya-jawab peserta-pembicara. Sedangkan materi workshopnya terdiri dari: Islam, toleransi beragama dan berkeyakinan; Islam, ICCPR dan Konstitusi Indonesia; regulasi dan peran negara dalam menjamin hak-hak Sipol, situasi toleransi beragama di Sumsel (Palembang).

Acara ini diharapkan bermanfaat untuk: pertama, memperkuat pemahaman dan pengetahuan para pemuka agama dan anggota FKUB tentang isu kebebasan beragama dan berkeyakinan di Indonesia. Kedua, meningkatkan kesadaran pemuka agama dan anggota FKUB tentang jaminan kebebasan agama dan berkeyakinan berdasarkan Kovenan Internasional tentang Hak Sipil dan Politik.

Target yang dicapai dalam workshop ini, antara lain: 1). Terbentuknya jejaring para pemuka agama dan para anggota FKUB yang cinta damai, baik di tingkat nasional maupun internasional. 2). Terlahir para pemuka agama yang tidak hanya memiliki pengetahuan tentang ICCPR, namun juga titik temu dengan konstitusi Indonesia dan ajaran agamanya masing-masing (Institute, 2016).

Kemudian, hari senin tanggal 5 Oktober 2015 Pemerintah Kota (Pemkot) Palembang mengelar sosialisasi bersama forum kerukunan umat beragama (FKUB) dan forum pemuda lintas agama (FPLA) di kota Palembang, di ruang rapat Parameswara, Melalui sosialisasi FKUB dan FPLA, diharapkan agar seluruh umat beragama di Kota Palembang sejalan dengan arah kebijakan pemerintah dalam pembangunan nasional, terutama dibidang agama, dan dapat memberikan peningkatan kualitas pemahaman agama di dalam kehidupan beragama, serta meningkatkan kerukunan inter dan antar umat beragama di segala bidang kehidupan bermasyrakat.

Ketua FKUB Kota Palembang, H. Syairozi, SH, M.Hum sebagai narasumber mengatakan, tujuan daripada sosialisasi ini guna memberikan pemahaman pada masyarakat, terutama tokoh-tokoh agama tentang peranan daripada FKUB menciptakan kerukunan antar umat beragama. Karena "Kita Indonesia ini bhnika tunggal ika, bermacam suku bangsa dan agama. Yang perlu kita bina adalah tetap rukun dalam kehidupan sehari hari,"

FKUB sendiri didirikan oleh pemerintah untuk menciptakan kerukuanan umat beragama. Mengingat yang paling pontensial konflik itu sebagian didasari dari agama. "Kita bersyukur bahwa Palembang sejak zaman Sriwijaya selalu aman dan damai. Tapi jangan sampai ada provokasi dan terjadi konflik,". Oleh karena itu, FKUB didirikan sebagai fasilisator dalam memberikan pemahaman agar tidak timbul fanatisme, dan umat beragama itu harus kompak". Untuk sejauh ini Kota Paembang jauh dari permasalahan dan ketegangan antara umat beragama. Syaroni mengatakan "Sejauh ini isu sara aman, tidak ada persoalan, jangan sampai kita di propokasi oleh pihak lain," (Sumsel G. , 2016).

Intizar, Vol. 23, No. 1, 2017 


\section{Kesimpulan}

Paradigma dapat diartikan sebagai cara pandang seseorang terhadap diri dan lingkungannya yang akan mempengaruhinya dalam berpikir (kognitif), bersikap (afektif), dan bertingkah laku (konatif). Paradigma juga dapat berarti seperangkat asumsi, konsep, nilai, dan praktik yang di terapkan dalam memandang realitas dalam sebuah komunitas yang sama, khususnya, dalam disiplin intelektual.

Sedangkan.toleransi diartikan sebagai suatu sikap atau sifat dari seseorang untuk membiarkan kebebasan kepada orang lain serta memberikan kebenaran atas perbedaan tersebut sebagai pengakuan hak-hak asasi manusia. Sehingga toleransi mengarah kepada sikap terbuka dan mau mengakui adanya berbagai macam perbedaan, baik dari sisi suku bangsa, warna kulit, bahasa, adat-istiadat, budaya, bahasa, serta agama. Ini semua merupakan fitrah dan sunnatullah yang sudah menjadi ketetapan Tuhan. Landasan dasar pemikiran ini adalah firman Allah dalam Qur'an surat Al-Hujurat ayat 13.

Paradigma integralistik dalam konteks kajian toleransi umat beragama, dimaknai sebagai paham dan konsep hubungan antar umat beragama yang toleran. Dalam paradigma integralistik, upaya mewujudkan toleransi umat beragama memerlukan kerjasama dan peran dari semua pihak, termasuk pemerintah dan tokoh agama. Hal ini karena, agama dan Negara merupakan suatu kesatuan yang tidak dapat tidak dipisahkan. Keduanya merupakan dua lembaga yang menyatu (interated). Ini juga memberikan pengertian bahwa Negara merupakan suatu lembaga politik dan sekaligus lembaga agama. Konsep ini menegaskan kembali bahwa Islam tidak mengenal pemisahan antara agama dan politik atau Negara. Konsep seperti ini sama dengan konsep teokrasi.

Toleransi umat beragama dibangun dalam beberapa aspek paradigma integralistik. Aspek-aspek tersebut yakni: toleransi dalam aspek ekonomi, budaya dan sosial keagamaan.

Salah satu model toleransi umat beragama melalui paradigma integralistik yang dilakukakan pemerintah Kota Palembang, yakni diadakannya berbagai kegiatan yang bertujuan untuk memperkuat sikap toleransi antar umat beragama. Kegiatan tersebut diantara nya Kodam II/Sriwijaya menggelar Komunikasi Sosial dan Silaturahmi dengan Forum Kerukunan Umat Beragama (FKUB) Sumsel, Selain kegiatan pertemuan dengan pemuka agama dari beragam agama yang ada di Palembang. Pemerintah juga mengadakan workshop dengan tema "Penguatan Kapasitas Bagi Pemuka Agama dan Dewan FKUB berbasis Toleransi". Workshop ini diselenggarakan oleh The Wahid Institute (Jakarta) bekerjasama dengan Lembaga Kajian Hukum Islam (LKHI) Palembang, Sumatera Selatan. 
Muhammad Noupal dan Erina Pane Paradigma Integralistik dan Toleransi Umat Beragama di Kota Palembang

\section{Daftar Pustaka}

Ali, D. (1989). Islam untuk Disiplin Ilmu Hukum Sosial dan Politik. Jakarta: Bulan Bintang.

Al-Munawar, S. A. (2005). Fikih Hubungan Antar Agama,. Jakarta: Ciputat Press. Hasyim, U. (1979). Toleransi Dan Kemerdekaan Beragama Dalam Islam Sebagai Dasar Menuju Dialog Dan Kerukunan Antar Agama. Surabaya: Bina Ilmu.

Institute, W. (2016, Oktober 30). Wahid Institute. Retrieved from Wahid Institute: http://www.wahidinstitute.org/v1/Agenda/Detail

Laksono, B. E. (2016, Oktober 20). Keanekaragaman Budaya Daerah (Sumatera Selatan - Palembang). Retrieved from Bimbim Elevens: http://bimbimelevens.blogspot.co.id/

Palembang, D. (2016, Oktober 20). Detak Palembang. Retrieved from Detak Palembang: http://detak-palembang.com, diakses tgl 20 Oktober 2016.

RI, D. A. (n.d.). Kompilasi Kebijakan dan Peraturan Perundang-undangan Kerukunan Umat Beragama.

Sumsel, C. (2016, Oktober 20). Click Sumsel. Retrieved from Pemerintah Kota Palembang Gelar Halal Bihalal: http://clicksumsel.com/pemerintah-kotapalembang-gelar-halal-bihalal/

Sumsel, G. (2016, Juli 18). Gelagat Sumsel. Retrieved from Gelagat Sumsel: http://gelagatsumsel.com/berita-2287

Sumsel, K. (2016, Oktober 30). Kemenag Sumsel. Retrieved from Kemenag Sumsel: https://sumsel.kemenag.go.id/berita 